\title{
Pawel Brusilo
}

Wroclaw University of Economics and Business

e-mail: pawel.brusilo@ue.wroc.pl

ORCID: 0000-0001-9138-5724

\section{TRANSITION TOWARDS ENERGY GENERATION FROM RENEWABLE SOURCES IN THE PEOPLE'S REPUBLIC OF CHINA IN THE YEARS 2000-2019}

\section{TRANSFORMACJA W STRONEC PRODUKCJI ENERGII ZE ŹRÓDEŁ ODNAWIALNYCH W CHIŃSKIEJ REPUBLICE LUDOWEJ W LATACH 2000-2019}

DOI: $10.15611 / \mathrm{e} 21.2019 .2 .06$

JEL Classification: N75, O13, P28, Q42

Summary: Over the last years, the People's Republic of China has undergone through the complex energy transition. This process sparked off because renewable energy (RE) sources became a more profitable and effective alternative for fossil fuels, which environmental, social and economic costs turned out to be incommensurate with the benefits. The increasing importance of RE sources in Chinese electricity generation has its reflection in the energy mix in 2019 over $26 \%$ of energy was produced from renewable energy sources. The following article includes a review of the most crucial changes in the energy transition process between 2000 and 2019. This paper also attempts to find the main reasons for the growing supply of energy sourced from RE sources. Electricity generation data, used in the study, present changes in the energy mix and showing examples of relevant infrastructural projects (i.e. the Three Gorges Dam in Hubei province) allows to take a broad view at the ongoing process of energy sources diversification in China.

Keywords: China, renewable energy sources, transition.

Streszczenie: Przez ostatnie lata Chińska Republika Ludowa przechodziła głęboką transformację energetyczną, ponieważ odnawialne źródła energii stają się coraz bardziej korzystną i efektywną alternatywą dla źródeł konwencjonalnych, których koszty środowiskowe, społeczne i ekonomiczne stają się niewspółmierne do osiąganych korzyści. Wzrost znaczenia OZE w produkcji energii elektrycznej w Chinach ma swoje odzwierciedlenie w miksie energetycznym, w którym w 2019 roku ponad 26\% energii elektrycznej było pozyskiwane ze źródeł odnawialnych. Artykuł stanowi przegląd najważniejszych przemian związanych z transformacją energetyczną w Chińskiej Republice Ludowej w latach 2000-2019. Prezentowane dane dotyczące wielkości produkcji energii elektrycznej pozwalają prześledzić dotychczasowe zmiany w strukturze energetycznej, a przykłady konkretnych obiektów infrastrukturalnych (takich jak Tama Trzech Przełomów w prowincji Hubei) umożliwiają szersze omówienie skutków postępującej dywersyfikacji źródeł energii w Chinach.

Słowa kluczowe: Chiny, odnawialne źródła energii, transformacja. 


\section{Introduction}

Low-carbon energy development concerns the future of humanity and China attaches great importance to low-carbon energy development and actively promotes energy consumption, supply, technology and institutional transformation. The country is ready to work with the international community to strengthen energy cooperation in all aspects, safeguard energy security, address climate change, protect the ecology and environment, promote sustainable development and bring more benefits to people around the world.

President of the People's Republic of China, Xi Jinping, October 2019 (Xi, 2019)

The energy transition is one of the most important challenges that every government and nation faces all across the world nowadays. The utilization of renewable energy (RE) sources is no longer a choice, but a necessity, due to tremendous, globally influential climate change. In recent years, the authorities of the People's Republic of China introduced impressive changes in the energy transition towards clean and renewable energy sources. The transformation of energy generation in this country is crucial due to the undisputed devastation of the natural environment and also increase in electric energy security.

Undoubtedly, the decrease of greenhouse gases emission (by investments in low-carbon energy sources such as solar, wind or hydropower stations) will have both positive impact on the environment as well as an increase of Chinese citizens' living standard. There are more reasons why the diversification of the energy mix is necessary. The growth of 'green power' usage has also an important influence on the competitiveness of the country's economy and its GDP growth (Vasylieva, Lyulyov, Bilan, and Streimikiene, 2019). There is significant research which shows how the development of this renewable energy industry resulted in Chinese companies taking up the running in global competition especially in the solar panel production industry (Cao, Rajarshi, and Tong, 2018).

The aim of this paper is to present a review of crucial accomplishments in the energy transition process in China between 2000 and 2019 and current Chinese energy mix. The paper is based on up-to-date statistics, reports and data which come from public sources such as the U.S. Energy Information Administration or China Electricity Council. It was important to find as diverse data about the power generation and supply industry as possible. To provide easy comparability of provided data all figures representing electric power generation are presented in unified units of energy - billion $\mathrm{kWh}$ (which is a standard international unit in statistical reports and an equivalent of $1 \mathrm{TWh}$ ). Mentioned literature presents a view at energy transition in China between 2000 and 2019 and comes mostly from Chinese researchers' publications. The foreign (non-Chinese) research about either energy generation or recent transition into renewable energy sources is in the minority. Nevertheless, international institutions evaluate and present the current situation of Chinese energy generation industry. The literature review, carried out by Yang W., Zhang 
X., Zhang X. in 2017, showed that this issue is indeed on the floor. The number of published both scientific and research articles about renewable energy in China raised from 25 in 1992 up to 969 in 2017 (with more than 9000 in total). Most of the relevant publications are related to RE sources themselves, but also electric cars mobility, carbon and greenhouse gases emission, energy consumption and power station capacity. Undoubtedly, year by year, those topics get greater attention among researchers (Yang, Zhang, and Zhang, 2019).

It is important to highlight the fact that this paper is limited to a very specific field of studies and focuses on actual and effective electricity generation per year, not installed generation capacity in power stations or electricity consumption across China. The study on the capacity (a maximum, possible in strictly controlled conditions and thermal limits, the electric output produced by electricity generator) could be the way of evaluating infrastructure and industrial potential but not tracking the energy transition. Another issue which has not been considered is related to energy consumption.

The actual consumption of electricity is not equal to annual energy generation due to technological limitations of infrastructure, energy losses during the process of energy conversion and, for instance, losses of energy over electric power transmission. Additionally, statistics presenting energy consumption could not be used to present the transition into RE sources, because they consider respective groups of electricity consumers such as material and non-material production sectors and households in a given period of time. Considering all of the above, neither installed generation capacity, nor electricity consumption, will be taken into consideration in this paper.

The article is structured as follows: chapter 2 presents an overview of past and present Chinese energy mix between 2000 and 2019. The time slot was limited to the past twenty years because earlier there had not been too many significant changes on the field of energy transition into 'green energy'. The growing trend of renewable energy sources usage gained currency at the beginning of the millennium (except hydropower which was commonly used far before the year 2000). Following, chapter 3 provides overall information about the share of each source in total energy generated from RE sources. It is important to present such a division because there are significant differences between each source (still hydropower is the main source of clean energy, but the other technologies are on the rise). Furthermore, the conclusions and summary are placed in chapter 4 .

\section{The transition of Chinese energy mix 2000-2019}

The electric power source portfolio has interestingly evolved since 2000. There are several reasons why renewable energy has been gaining popularity in the People's Republic of China for the last twenty years. This shift is not only related to the desire to preserve the environment but also with measurable effects on the Chinese economy. 
The table below shows the energy mix and percentage share of RE sources in total energy production (in billions of $\mathrm{kWh}$ ). It is worth underlining that for many years Chinese electricity generation was still very diverse and the role of renewable energy sources increases year by year. The most impressive growth in energy generated from RE sources is visible within resent years. The volume of this type of electricity supply grew up by $74.44 \%$ from 2013 , but in the same period of time, energy from fossil fuels rose only by $27.50 \%$. Such a change was caused mainly by new strategies towards energy supply industry implemented by central authorities (Burandt, Xiong, Löffler and Oei, 2019). The specific composition of RE sources portfolio will be presented as follows.

Table 1. Energy generation in billion kWh by sources in China (2000-2019)

\begin{tabular}{|c|c|c|c|c||c||}
\hline Year & $\begin{array}{c}\text { Total } \\
\text { production }\end{array}$ & Nuclear & Fossil fuels & RE sources & $\begin{array}{c}\text { Share of RE sources in total } \\
\text { energy production (\%) }\end{array}$ \\
\hline 2000 & 1,280 & 16 & 1,041 & 223 & $\mathbf{1 7 . 4 2}$ \\
\hline 2001 & 1,427 & 17 & 1,132 & 278 & $\mathbf{1 9 . 4 8}$ \\
\hline 2002 & 1,584 & 25 & 1,271 & 288 & $\mathbf{1 8 . 1 8}$ \\
\hline 2003 & 1,810 & 42 & 1,484 & 284 & $\mathbf{1 5 . 6 9}$ \\
\hline 2004 & 2,104 & 48 & 1,702 & 354 & $\mathbf{1 6 . 8 3}$ \\
\hline 2005 & 2,373 & 50 & 1,925 & 398 & $\mathbf{1 6 . 7 7}$ \\
\hline 2006 & 2,717 & 52 & 2,227 & 438 & $\mathbf{1 6 . 1 2}$ \\
\hline 2007 & 3,108 & 59 & 2,560 & 489 & $\mathbf{1 5 . 7 3}$ \\
\hline 2008 & 3,297 & 65 & 2,623 & 609 & $\mathbf{1 8 . 4 7}$ \\
\hline 2009 & 3,528 & 66 & 2,804 & 658 & $\mathbf{1 8 . 6 5}$ \\
\hline 2010 & 3,988 & 71 & 3,133 & 784 & $\mathbf{1 9 . 6 6}$ \\
\hline 2011 & 4,466 & 83 & 3,590 & 793 & $\mathbf{1 7 . 7 6}$ \\
\hline 2012 & 4,739 & 93 & 3,648 & 998 & $\mathbf{2 1 . 0 6}$ \\
\hline 2013 & 5,175 & 111 & 3,957 & 1,107 & $\mathbf{2 1 . 3 9}$ \\
\hline 2014 & 5,392 & 124 & 3,985 & 1,283 & $\mathbf{2 3 . 7 9}$ \\
\hline 2015 & 5,567 & 161 & 4,008 & 1,398 & $\mathbf{2 3 . 7 6}$ \\
\hline 2016 & 5,895 & 198 & 4,157 & 1,540 & $\mathbf{2 6 . 1 2}$ \\
\hline 2017 & 6,279 & 233 & 4,398 & 1,648 & $\mathbf{2 6 . 2 4}$ \\
\hline 2018 & 6,995 & 295 & 4,923 & 1,777 & $\mathbf{2 5 . 4 0}$ \\
\hline 2019 & 7,325 & 349 & 5,045 & 1,931 & $\mathbf{2 6 . 3 6}$ \\
\hline
\end{tabular}

Source: own elaboration based on (U.S. Energy Information Administration, 2019; China Electricity Council, 2020).

There are several reasons why the authorities of the People's Republic of China decided to implement new strategy and actions regarding gradual energy transition towards more 'green sources'. First of all, since China introduced a new economic 
development model (called Găigé kāifàng - the opening of China) in 1978, a rapid development of this economy (but still based on smokestack industry) was possible, but it also caused many contingent effects such as increasing urbanization and overpopulation which resulted in the growth of pollution emission and natural environment devastation in the XXI century (Lin, Khanna, Liu, Teng, and Wang 2019).

China, equally among other countries, faces dangerous and unpredictable effects of global climate change. In this country, despite changes in the energy mix, the energy generated from fossil fuels still plays a leading role (73.64 \% in 2019). That also has an impact on carbon dioxide $\left(\mathrm{CO}_{2}\right)$ emission, which is one of the reasons for progressing climate crisis not only in China but on the entire planet.

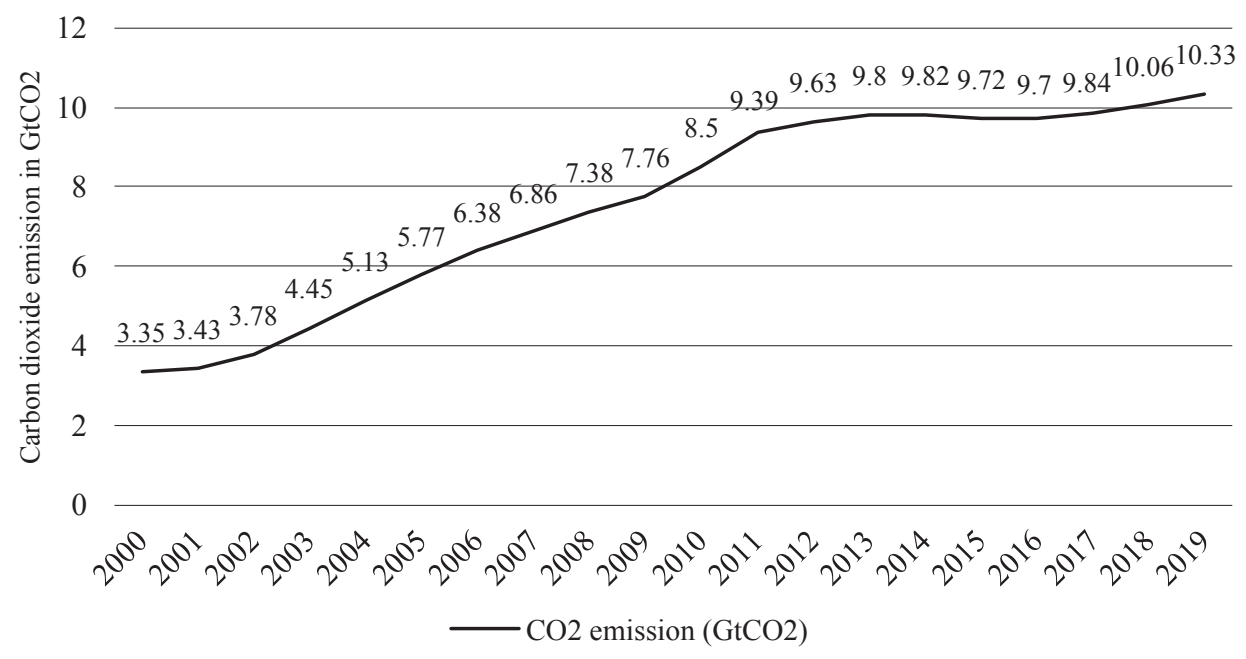

Figure 1. Emission of carbon dioxide (in gigatons of $\mathrm{CO}_{2}$ ) in the years 2000-2019

Source: own elaboration based on (Global Carbon Atlas 2020).

Figure 1. demonstrates how carbon dioxide emission has flattened over the last years. China is still indisputably the biggest world energy consumer and the largest emitter of toxic and environmentally harmful gases (Lin et al., 2019). Hence, greenhouse gases limitation is one of the key reasons for the increasing importance of renewable energy sources (including among others methane $\left(\mathrm{CH}_{4}\right)$ and nitrous oxide $\left(\mathrm{N}_{2} \mathrm{O}\right)$ ). It is visible that over the last few years the $\mathrm{CO}_{2}$ emission growth has already slowed down and from now on it is supposed to rapidly change course (Burandt, Xiong, Löffler, and Oei, 2019). China also signed the Paris Agreement (which entered into force on the 4th of November 2016) and is obliged to run a struggle to achieve short and long-run goals such as decrease of world average temperature growth by $2{ }^{\circ} \mathrm{C}$ by 2050 (United Nations Framework Convention on Climate Change [UNFCCC], 2015). The final provisions from the international treaty were 
reflected in the $14^{\text {th }}$ Five-Year Plan (2021-2025), which has been adopted and which measurably accelerates the energy transition dynamics by introducing investments in RE infrastructure and financially supports projects based on RE sources (China National Renewable Energy Centre, 2019).

However, the constant and uninterrupted industrial development is as important as natural environment protection (in the context of upcoming strategies). The future of conventional sources of energy like coal, coke or natural gas worries the experts and policymakers. The problem is that attempting to effectively predict a future situation on those markets may not be possible in a long run, because of difficult to guess fluctuations.

In this case, renewable resources have an unmistakable advantage - they are generally available at no-cost and (with some exceptions like wind or solar power, which are closely related with weather conditions) they are unlimited and available far more stably. Hence, from the electricity generation stability point of view, RE sources are coming in the foreground and provide potential reliability.

Diversification of energy sources and the process of petering out fossil fuels (in a longer perspective) can be a very effective way of reaching potential additional advantages in present days. A recent study, based on portfolio theory model, shows that the increasing role of renewable sources in China may cause significant risk minimization in 2030 perspective (i.e. limiting the risk of fossil fuels prices fluctuation). In addition, it has been proved that the inclusion of both, non-fossil and non-hydropower generation will have a positive impact on electric energy costs (Zhang, Zhao, and Xie, 2018).

The change in the Chinese power generation has also an impact on the national renewable energy industry and a volume of related goods such as solar panels or wind turbines. The global technological competition in this market is fierce. Production and export of goods related to RE sources can be very profitable. In 2018, X. Cao, A. Rajarshi and J. Tong published their research results which showed that in 2016 China had exported mainly medium and medium-high technical complexity products and their overall technical level had been estimated at the middle of the global industrial value chain. Between 2007 and 2016 Chinese main export categories were primarily as follows: solar cells, solar power stations and solar lighting equipment. Researchers, adducing United Nations COMTRADE database estimated that Chinese total value of RE products export in 2016 reached 83,40 billion USD and accounted for nearly $24.31 \%$ of the world export share, ranking first in the world (Cao, Rajarshi, and Tong, 2018, p. 2).

By presenting all of the examples above, it is possible to make an assumption about the possible reasons for energy transition toward RE sources. This process is not only motivated by the desire to slow down global warming, decrease pollution emission and restore devasted natural environment. Doubtlessly, it is also an economic profit-driven change to take the chance of exploiting increasing popularity of technologies based on renewable energy sources. 


\section{Share of individual renewable energy sources in Chinese power generation in 2000-2019}

Generally, during the discussed period, hydropower was the most developed and commonly used renewable energy source, but in recent years we can observe a growing supply of energy generated from other RE sources - mainly solar (photovoltaic panels) and wind (turbines). The diversification of power sources is a key element of structural strategic changes implemented by Chinese authorities in recent years. The chart below (Figure 2) shows the shift in energy mix generation coming from renewable sources between 2000 and 2019. Interestingly, over the last few years, more advanced technologies have been used to produce electricity including biomass and waste incineration, tide power, hydrogen fuel cells and solar energy coming from thermal panels.

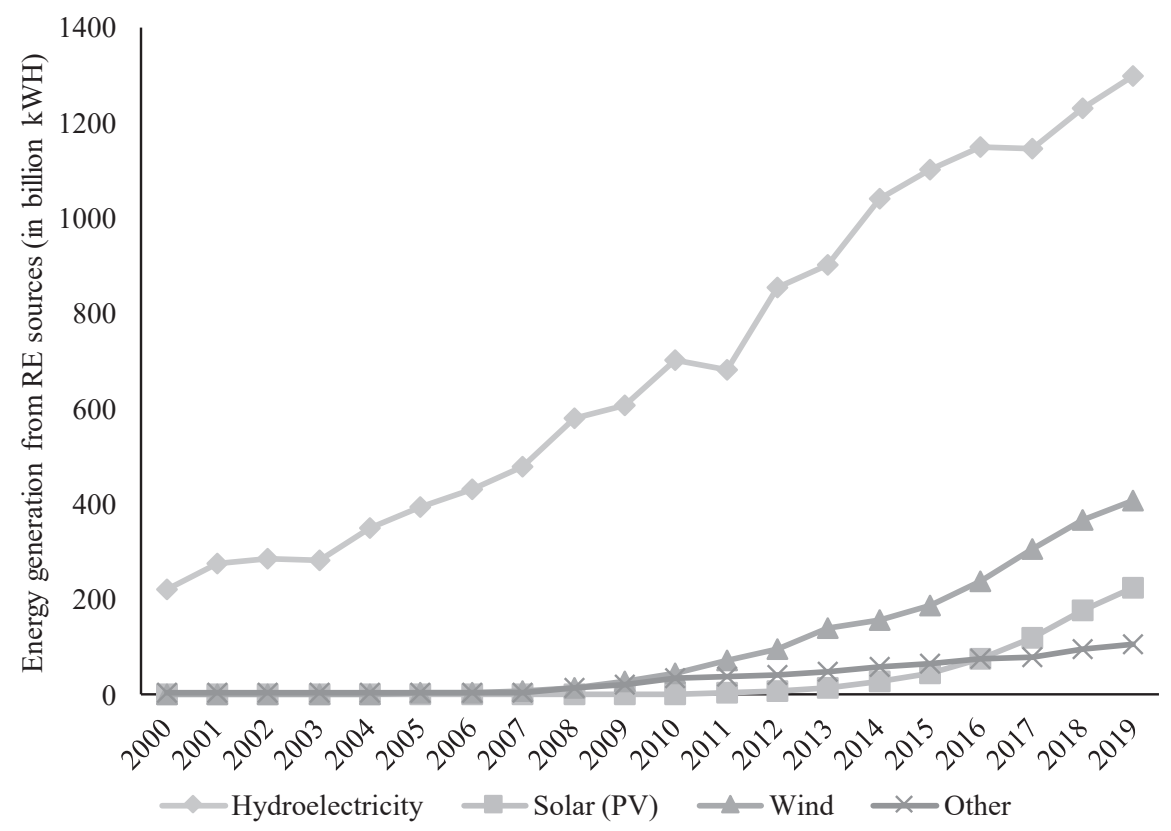

Figure 2. Energy generation from renewable energy sources in China 2000-2019 (in billion kWh)

Sources: own elaboration based on (U.S. Energy Information Administration, 2019; China Electricity Council, 2020).

Due to absolutely nonsignificant share in total energy generation from those newly introduced in larger-scale RE systems, they were included in a column entitled "other". 
It is very important to emphasise that for nearly the last twenty years, China has made an impressive shift, starting from the point where the only renewable source of energy used for its production was hydropower. It is understandable as this source of renewable energy requires very limited investments in infrastructure, generally available technology such as water turbines, turbo-generators and accessible watercourses.

Chinese geographical position has allowed this country to conduct dynamic development of hydropower plant infrastructure for the last decades. Till now, China possesses the highest number of dams (approximately half of world's total), the biggest amount of energy generated from hydropower (around 20\% of the world's total) and a vast infrastructure such as the Three Gorges Dam in Hubei Province (Liu, Liu, Zang, Tian, Liu, Yang, Jia, You, and Liu, 2013). The cornerstone of this power station, located on the China's longest river Yangtze, was laid in 1994 and in 2012 it perched on the top world list (USGS, 2020). Just in the first half of 2018, this power station generated 38.9 billion $\mathrm{kWh}$ of electricity.

Such projects, despite the important contribution of enhancing the renewable energy source in many cases have adverse effects. The studies show that the functioning of the Three Gorges Dam has a harmful effect on the hydrological cycle in the mid-lower Yangtze River (within approximately $260 \mathrm{~km}$ downstream from the power station) due to water temperature changes (Xiong and Yin, 2020).

Moreover, building such monumental structures affects local communities, forcing the relocations of 1.13 million inhabitants of surrounding villages and towns (Wilmsen, 2016). Another issue, related to this power station, is connected with surrounding rivers and wetlands drying up process. Those changes in the natural environment are not only potential danger for the climate itself, but also for biodiversity hot spots and endangered species. The Three Gorges Dam is not an exception - the same unsustainable hydropower infrastructure development occurs along other rivers i.e. the $\mathrm{Nu}$ and Mekong rivers (Qiu, 2011).

Indeed, the hydropower in China has its potential as a 'clean energy' source, lowering the carbon dioxide emission in long-run perspective and providing stable electric energy supply, but (as the mentioned studies show) the infrastructure development is carried out at a great environmental and social cost.

Interestingly enough, the future of this renewable energy source can be at stake due to a continually progressive climate change. Jing-Li Fan and the other researchers, mainly from China University of Mining \& Technology in Beijing, published in 2020 their econometric model and analysis of future electricity generation from this RE source and came to the following conclusions. They found out that existing infrastructure will be very sensitive to climate fluctuations such as heavy rainfalls, floods, long heatwaves and extreme droughts, so the constructions should be constantly adapted to the changing environment.

Additionally, the researchers pointed out that the impact of climate factors will affect Chinese provinces unequally - hydropower stations in Southern China will 
be more vulnerable, so the authorities should pay more attention to those facilities. Finally, due to a significant uncertainty related with hydropower as a source of energy (which can be strongly affected by climate changes) the other sources of renewable energy should be simultaneously developed to complete the electricity gaps (Fan, $\mathrm{Hu}$, Zhang, Kong, Fengyu, and Mi, 2020). Either way, the previous examples show that despite the circumstances, hydropower stations will be continuously a primary renewable energy source in China for years to come.

Solar photovoltaic (PV) and thermal power sources are not as widely used in China as hydropower, but still, those RE sources hold great potential. First of all, this country, located in South-East Asia, has higher than average solar resources. In China, more than two-thirds of territory receives over two thousand hours of sunshine every year (annual solar radiation is $5.02 \times 10^{6} \mathrm{~kJ} / \mathrm{m}^{2}$ ) which is an equivalent of $1.7 \times 10^{12}$ tons of coal per year considering the whole country (Xu, Xie, and Xie, 2020).

The solar panel technology itself has many advantages. There is no danger of exhaustion, it is safe, clean, reliable and it can be installed anywhere, despite the lay of the land, which is quite important considering the fact that most of Western China territory is rather mountainous with many outlying human habitats. It is also important to emphasise that this technology is developing rapidly and it will increase its efficiency year by year ( $\mathrm{Li}, 2019)$.

This source of energy was not practically exploited before 2007 and the production of the related goods, such as photovoltaic panels, was in an initial stage. The breakthrough occurred when two important strategic projects were announced and finally implemented in 2012 - "Golden Sun Project" and "Photovoltaic Building" - in order to introduce a preferential policy of VAT for PV panels (tax reduction by 50\%), adjust dedicated funds for PV installation, reduce net electricity price generated from solar power and encourage private enterprises to invest in R\&D over innovative technology of PV production by offering public procurements $(\mathrm{Li}$, Lin, Tan, Wu, Wang, De, and Huang, 2020).

These improvements and facilitations resulted in the continues increase of this source share in total energy generation (224 billion $\mathrm{kWh}$ in 2019). However, there is another renewable energy source, which is also worth considering, as one of the most important in the current Chinese energy mix.

Wind energy (air kinetic energy) represents an essential and dynamically growing alternative to other RE sources. It has a relatively lower greenhouse gas emission in the infrastructure production and the use of clean technology without any significant harmful impact on natural ecosystems. Recent studies show that China is also located in a friendly environment for wind turbines with approximately 17,80 million GWh total annual energy generation availability.

To use such vast resource, in 2016 Chinese authorities planned to increase the electricity generation from wind power to $378-450$ billion kWh by 2020 and $900-$ 1000 billion $\mathrm{kWh}$ by 2030 , whereby the first objective has already been achieved (Feng, Feng, Wand, and King, 2020). 
However, it was not the only programme implemented in order to force the acceleration of introduction of wind energy generation facilities. Wenfeng Liu and the other researchers from Beijing North China Electric Power University, published in 2019 their recent studies over the effectivity of government economic interventionism. The research resulted in the following conclusions. The Special Fund Mechanism ${ }^{1}$ had a way greater impact on wind power generation facilities development than the VAT and corporate income tax preferential policies. Surprisingly enough, neither the growth of general power demand, nor fluctuations of Chinese GDP has a significant influence on the wind generation increase (Liu, Zhang, Bu and Feng, 2019).

Other sources of renewable energy are definitely rarely used in the process of electricity generation. In this group following RE sources are classified: ocean tide energy, biomass and waste incineration, biofuels, hydrogen fuel cell, geothermal and heat pumps. All of them can offer economic effects but their role in energy production (comparing to those sources mentioned before) has a marginal significance. Nevertheless, their potential has been spotted by investors and presumably by the next decade their contribution in total energy production will grow. For instance, it is presumed that by 2030 , electricity generation from biomass will reach 22.35 billion $\mathrm{kWh}$ from agricultural and forestry residues, 21.15 billion $\mathrm{kWh}$ from municipal solid waste and 4,9 billion $\mathrm{kWh}$ from biogas (He, Zhu, and Lin, 2019).

\section{Conclusions}

The review of past and present Chinese energy mix has proved that this country has already made a significant shift towards a more diverse portfolio of electricity generation sources. The reasons of such energy transition are also very complex, not only economically driven but also related to attempts to increase the level of natural environment preservation.

The fundamental problem is that the example of studies over the Three Gorges Dam and the other comparable facilities shows that the increase of renewable energy sources utilisation leads even to the impairment of natural ecosystem conditions (in a context of drying out smaller watercourses or swamps and changing an average temperature of water in rivers) and the broadscale relocations of inhabitants. It creates a problem to pass unquestioned evaluation on the hydropower usage growth, which causes many issues related to the natural environment.

However, there are many examples that within the last twenty years the energy transition has resulted in the growth of popularity of technologies which are much less harmful to natural ecosystems. Solar, wind and other renewable energy sources do not substantially interfere with fauna and flora. Such projects can be presented as new eco-friendly solutions to global warming and climate change. Additionally,

\footnotetext{
${ }^{1}$ The Special Fund Mechanism was introduced in 2011 together with Interim Measures on the Collection, Use and Management of the Renewable Energy Development Fund.
} 
many alternative sources of renewable energy are developed, which shows the struggle for innovative technologies and RE portfolio diversification.

Observing ongoing changes within the energy generation sector, it is still clearly visible that conventional energy, based on fossil fuels such as coal, coke and natural gas, is in the ascendant. For the last twenty years, the intensification of RE sources use has been accompanied by the growth of energy generation from highly greenhouse gases emissive sources. For the last ten years the trend of $\mathrm{CO}_{2}$ emission has flattened (and, by the end of 2019, it totalled $10.33 \mathrm{Gt}$ of $\mathrm{CO}_{2}$ ), but still China is considered the biggest worldwide emitter. In this context, the coming years will be crucial and hopefully, implemented policies and strategies will have the desired effects on the emission.

No matter which renewable energy source is being considered, they are on a general upward trend despite many disadvantages (like all power sources, both conventional and renewable). The challenge for this Chinese economy for the next years is to keep such significant growth stable and resistant to negative climate change effects. Especially the hydropower stations are exposed the most to climate fluctuations and, for instance, detailed strategic planning and forecasting may allow the authorities to counter prospective damages to an infrastructure, voltage drop or groundwater loss.

It should be noted that electricity generation from fossil fuels has, in the context of climate change, an advantage - these sources of energy provide a very stable power supply, despite the weather conditions, but on the other hand, this technology is still exposed to industrial changes, market fluctuations and global trends towards the protection of the natural environment.

The data presented in this article also pave the way for an evaluation of the current share of renewable energy sources in Chinese total energy generation. Thanks to sourcing amounting to $25.40 \%$ of electricity from RE sources in 2018 , China takes the first place in the global energy from RE sources generation ranking (REN21, 2019) and is on course for becoming one of the first countries to reach a significant fossil fuel reduction in foreseeable future.

\section{References}

Burandt, T., Xiong, B., Löffler, K., \& Oei, P. Y. (2019). Decarbonizing China's energy system - Modeling the transformation of the electricity, transportation, heat, and industrial sectors. Applied Energy, (255).

Cao, X., Rajarshi, A., \& Tong, J. (2018). Technology evolution of China's export of renewable energy products. International Journal of Environmental Research and Public Health, 15(8).

China Electricity Council. (2020). 2019年全国电力工业统计快报一览表 $\mid$ List of statistical reports of the national electric power industry in 2019. Retrieved from http://www.cec.org.cn/

China National Renewable Energy Centre. (2019). China Renewable Energy Outlook. Beijing: Energy Research Institute of Academy of Macroeconomic Research/NDRC. Retrieved from http://www. boostre.cnrec.org.cn 
Fan, J. L., Hu, W. J., Zhang, X., Kong, L. S., Fengyu, L., \& Mi, Z. (2020). Impacts of climate change on hydropower generation in China. Mathematics and Computers in Simulation, (167), 4-18.

Feng, J., Feng, L., Wand, J., \& King, C. (2020). Evaluation of the onshore wind energy potential in mainland China - based on GIS modeling and EROI analysis. Re-sources, Conservation and Recycling, (152).

Global Carbon Atlas. 2020. CO2 Emissions, Retrieved from http://www.globalcarbonatlas.org/en/ $\mathrm{CO} 2$-emissions

Han, D., Li, T., Feng, S., \& Shi, Z. (2020). Does renewable energy consumption successfully promote the green transformation of China's industry? Energies, 13(1), 229.

He, J., Zhu, R., \& Lin, B., (2019). Prospects, obstacles and solutions of biomass power industry in China. Journal of Cleaner Production, (237).

Huang, Y, Yang, L., Gao, C., Jiang, Y., \& Dong, Y. (2019). A novel prediction approach for short-term renewable energy consumption in China based on improved Gaussian Process Regression. Energies, 12(21).

Li, H., Lin, H., Tan, Q., Wu, P., Wang, C., De, G., \& Huang, L. (2020). Research on the policy route of China's distributed photovoltaic power generation. Energy Reports, (6), 254-263.

Li, R., (2019) China's photovoltaic power generation technology and application. IOP Conference Series: Earth and Environmental Science, (300).

Li, Y., Chiu, Y., \& Lu, L. C. (2019). New energy development and pollution emissions in China. International Journal of Environmental Research and Public Health, 16(10).

Lin, J., Khanna, N., Liu, X., Teng, F. \& Wang X. (2019). China's non-CO2 greenhouse gas emissions: Future trajectories and mitigation options and potential. Scientific Reports, (9).

Liu, J., Zang, C., Tian, S., Liu, J., Yang, H., Jia, S., You, L., \& Liu, B. (2013). Water conservancy projects in China: Achievements, challenges and way forward. Global Environmental Change, 23(3), 633-643.

Liu, L., Wang, Z., Xin, Z., Qiang, H., \& Xue, Y. Cheng. (2010). Solar energy development in ChinaA review. Renewable and Sustainable Energy Reviews, 14(1), 301-311.

Liu, W., Zhang, X., Bu, Y., \& Feng, S. (2019). The effectiveness of China's renewable energy policy: An empirical evaluation of wind power based on the framework of renewable energy law and its accompanying policies. Emerging Markets Finance and Trade, (1), 1-16.

Liu, Y., Li, F., Ren, J., Ren, G., Shen, H., \& Liu, G. (2019). Solar thermal power generation technology research. E3S Web of Conferences, (136).

Ministry of Finance of the People's Republic of China. (2011). Interim measures on the collection, use and management of the Renewable Energy Development Fund. Retrieved from https://policy. asiapacificenergy.org

Qin, J. (2018). The status and prospect of new energy and renewable energy in China. AIP Conf. Proc., (1971).

Qiu, J. (2011). China admits problems with Three Gorges Dam. Nature. Retrieved from http://www. nature.com

REN21. (2019). Renewables 2019 - Global Status Report. Retrieved from http//www. ren21.net

United Nations Framework Convention on Climate Change (UNFCCC). Paris Agreement 2015.

U.S. Energy Information Administration. (2019). China - Total Net Annual Electricity Generation. Retrieved from http://www.eia.gov

USGS. (2020). Three Gorges Dam: The world's largest hydroelectric plant. Retrieved from http://www. usgs.gov

Vasylieva, T., Lyulyov, O., Bilan, Y., \& Streimikiene, D. (2019). Sustainable economic development and greenhouse gas emissions: The dynamic impact of renewable energy consumption, and corruption. Energies, 12(17).

Wilmsen, B. (2016). After the deluge: A longitudinal study of resettlement at the Three Gorges Dam, China. World Development, (80), 41-54. 
Xi, J. (2019) President's congratulatory letter to Taiyuan Energy Low Carbon Development Forum, Xinhua, Retrieved from http://www.chinadaily.com.cn

Xiong, Y. J., Yin, J. (2020). How the Three Gorges Dam affects the hydrological cycle in the mid-lower Yangtze River: A perspective based on decadal water temperature changes. Environmental Research Letters, (15).

Xu, M., Xie, P., \& Xie, B. C. (2020). Study of China's optimal solar photovoltaic power development path to 2050. Resources Policy, (65).

Yang, W., Zhang, X., \& Zhang, X. (2019). A bibliometric review of China's new energy in 2017. IOP Conf. Ser.: Earth Environ. Sci, (252).

Ye, L. C., Lin, H. X., \& Tukker, A. (2019). Future scenarios of variable renewable energies and flexibility requirements for thermal power plants in China. Energy, (167), 708-714.

Zhang, J., Liu, J., Mi, Z., \& Zhao, Q. (2019). Analysis of China's new energy development in new period of renewable energy subsidy. IOP Conf. Ser.: Earth Environ. Sci, (371).

Zhang, S., Zhao, T., \& Xie, B. C. (2018). Analysis of power generation mix in China: An evaluation based on portfolio theory. Energy Procedia, (145), 163-168. 